\title{
NIT1 Gene
}

National Cancer Institute

\section{Source}

National Cancer Institute. NIT1 Gene. NCI Thesaurus. Code C126583.

This gene plays a role in apoptosis and the catabolism of nitrogen compounds. 